\title{
Procedural And Distributive Justice As Mediators Of The Relationship Between Interactional Justice And Work Outcomes: An Empirical Study Of The UAE Public Health Care Sector
}

Thamna S. Al Afari, Abu Dhabi University, United Arab Emirates Hossam M. Abu Elanain, Abu Dhabi University, United Arab Emirates

\begin{abstract}
This study examined the direct and indirect effects of different dimensions of organizational justice on organizational citizenship behaviors, and turnover intention in the context of the United Arab Emirates (UAE) healthcare sector. A questionnaire was administered to a random sample of 448 employees working in three different public hospitals in the UAE. The study used descriptive statistics, factor analysis, correlation analysis, and regression analysis to analyze the data. The results revealed that perceptions of the three organizational justice dimensions (interactional justice, procedural justice, and distributive justice) have a direct influence on employees' organizational citizenship behaviors and turnover intention. In addition, the results showed that interactional justice has an indirect effect on both organizational citizenship behaviors and turnover intention through procedural and distributive justice. This study is one of the first empirical studies of its kind to demonstrate the role of procedural and distributive justice as mediators between interactional justice and employees' work attitudes and behaviors. In conclusion, the results of this study indicate that each of the dimensions of organizational justice, which affect employee attitudes and behavior in the healthcare sector, gives us a better understanding of organizational justice and its dimensions and its influence.
\end{abstract}

Keywords: Organizational Justice; Interactional Justice; Procedural Justice; Distributive Justice; Organizational Citizenship Behaviors; Turnover Intention; Healthcare Sector; United Arab Emirates

\section{INTRODUCTION}

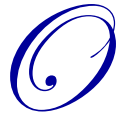

rganizations always depend on human capital, because it is vitally important for their success (Nadiri \& Tanova, 2010). One of the major challenges facing organizations, regardless if they are private or public, in western or in non-western contexts, such as the Gulf Cooperation Council (GCC) countries in general and the United Arab Emirates (UAE) in particular, is retaining talented and loyal employees (Suliman \& Al Obaidli, 2011). This is because the costs of recruiting, selecting, and training new employees regularly exceed $100 \%$ of the annual salary of employees who are already in the organizations (Cascio, 2006). Therefore, organizations invest a lot in their employees in order to maintain and retain them (Macey et al., 2009).

Many studies in western countries claim that the healthcare sector is problematic, stressful, and more risky compared to the other sectors (e.g., Rashid \& Jusoff, 2009). Hence, many research studies focus on investigating the antecedents of organizational citizenship behaviors (OCB) (Gilbert, Laschinger, \& Leiter, 2010) and turnover intention in the health care sector (Albrecht \& Andreetta, 2011; Brewer, Kovner, Greene, Tukov-Shuser, \& Djukic, 2012; Harlos, 2010). However, few studies on this topic have been done in a non-western context. In an attempt to 
fill this gap, this study investigates the factors that can affect organizational citizenship behaviors and employee turnover intention in the healthcare sector in the UAE.

Many researchers have indicated that there are many factors that can affect organizational citizenship behaviors and turnover intention. They have suggested that organizations offering better and improved organizational justice are more likely to succeed in attracting and retaining valuable staff (Abu Elanain, 2010a; Ince \& Gül, 2011; Lambert et al., 2010). The reason is that organizational justice is associated with organizational commitment (Azeem, 2010), employee job satisfaction, and organizational citizenship behaviors (Olkkonen \& Lipponen, 2006). Furthermore, previous research has found a relationship between organizational justice and turnover intention (Hassan \& Hashim, 2011), as well as between organizational justice and organizational citizenship behaviors (Al-Hyasat, Al Shra'ah, \& Abu Rumman, 2013; Colquitt et al., 2001; Cohen-Charash \& Spector, 2001; Greenberg, 1993; Niehoff \& Moorman, 1993; Chegini, 2009; Cheung, 2013; Cloninger, Ramamoorthy, \& Flood, 2011; Erkutlu, 2011). However, this relationship has rarely been studied in a non-western context (Bagtasos, 2011; Abu Elanain, 2010a). Moreover, few studies have examined the mediating impact of organizational justice dimensions of procedural and distributive justice on the relationships between interactional justice, organizational citizenship behaviors, and turnover intention (Hemdi \& Nasurdin, 2008).

Based on the above, the primary purpose of this study is to investigate the main factors that affect organizational citizenship behaviors and turnover intentions of employees in the public healthcare sector in the UAE. In addition, the study examines the mediating effects of procedural and distributive justice on the relationships between organizational justice (interactional justice), organizational citizenship behaviors, and turnover intention. In other words, this study addresses three research questions: what type of organizational justice is needed to implement an effective strategy for retaining healthcare employees and promoting organizational citizenship behaviors?; Do procedural and distributive justice mediate the effect of interactional justice on organizational citizenship behaviors?; and do procedural and distributive justice mediate the effect of interactional justice on turnover intentions of healthcare employees?

This study attempts to fill the gap in the literature and contribute to the existing research in the Arab context by investigating the factors that could motivate healthcare employees to increase extra-role behavior through organizational citizenship behaviors. It is one of the first empirical studies of its kind to demonstrate the roles of procedural and distributive justice as mediators between interactional justice and employee work attitudes and behaviors.

\section{LITERATURE REVIEW}

\section{Organizational Justice}

Organizational justice refers to how people are treated within an organization and their perceptions of fairness within organizations. Greenberg (1990) defined organizational justice as having "grown around attempts to describe and explain the role of fairness as a consideration in the workplace" (p. 400). There are three dimensions of organizational justice: procedural, distributive, and interactional justice (Bakhshi, Kumar, \& Rani, 2009).

Distributive justice refers to the fairness of distribution and allocations of outcome (Colquitt et al., 2006; Colquitt, Greenberg, \& Zapata-Phelan, 2005; Greenberg, 2006) like a promotion and payment (Wang, Liao, Xia, \& Chang, 2010). Adams (1965) stated that distributive justice includes employee perceptions about how fairly job demands and rewards are distributed among them. Procedural justice implies the perceived fairness of procedures used to allocate resources (Colquitt et al., 2005). Interactional justice reflects the quality of interaction or treatment between employees in an organization (Colquitt et al., 2001). In other words, interpersonal justice refers to the manner in which people relate to supervisors at work, while informational justice refers to the quality of communication between the employee and his or her supervisor in the organization (Suliman \& Al Kathairi, 2013).

Previous studies indicate that there is a clear impact of organizational justice on employee attitudes and behaviors, such as employee health (Elovainio, van den Bos, Linna, Kivimaki, Ala-Mursula, Pentti, \& Vahtera, 2005), organizational commitment (Bakhshi et al., 2009) psychological empowerment (Kamalian et al., 2010), 
organizational citizenship behaviors (Chegini, 2009; Rezaiean et al., 2010), job satisfaction (Elamin \& Alomaim, 2011; Halepota \& Shah, 2011), reduced stress levels (Greenberg, 2006), and turnover intention (Owolabi, 2012).

In other words, research on organizational justice show that perception of organizational justice has a positive relationship with many desirable work outcomes. For example, it contributes to enhancing organizational citizenship behaviors, organizational commitment, job satisfaction, trust, turnover intentions, and job performance (Cohen-Charash \& Spector, 2001; Colquitt et al., 2001; Crow, Lee, \& Joo, 2012; Erkutlu, 2011; Nowakowski \& Conlon, 2005; Wang et al., 2010; Whitman, Caleo, Carpenter, Horner, \& Bernerth, 2012). In addition, perceived organizational justice has a negative relationship with some undesirable work outcomes, such as counterproductive work behaviors and turnover intentions (Cohen-Charash \& Spector, 2001; Colquitt et al., 2001; Nowakowski \& Conlon, 2005). In the UAE, Fernandes and Awamleh (2006) examined the impact of three types of organizational justice on both UAE nationals and expatriate groups. They collected data from employees who were working in different organizations in the UAE, and found that distributive and interactional justice has a significant influence on satisfaction and performance of UAE nationals group, while all types of justice influence satisfaction but do not affect the performance of expatriate groups.

\section{Turnover Intention}

Turnover can be defined as the departure of an employee from an organization (Owolabi, 2012). This study focuses on turnover intention rather than using actual turnover, since several studies claim that turnover intention is considered a strong predictive variable of actual turnover (Lee \& Liu, 2007). Also, it is a reliable and good indicator for actual turnover. In other words, examining turnover intention will help to understand the reasons for actual turnover (Liu \& Onwuegbuzie, 2012). Turnover intention is defined as thinking of quitting, intention to search, and intention to quit (Mobley, Homer, \& Hollingsworth, 1978).

\section{Organizational Citizenship Behaviors}

Organizational citizenship behaviors is defined as an action that is non-obligatory and not explicitly recognized by any type of organizational reward systems and that in general improves the functioning of an organization (Organ, Podsakoff, \& MacKenzie, 2006). Organizational citizenship behaviors have received attention in both organizational and business research (Arthaud-Day, Rode, \& Turnley, 2012). They play a significant role in improving the effectiveness and efficiency of an organization (Organ et al., 2006). They enhance co-workers and managerial productivity, strengthen an organization's ability to attract and retain the best employees, and help an organization to adapt more effectively to organizational change (Podsakoff et al., 2000). In service organizations, organizational citizenship behaviors are very important and required for delivering high quality service (Benjamin, 2012), as well as for reducing turnover intention (Podsakoff, Whiting, Podsakoff, \& Blume, 2009).

\section{The Relationship between Organizational Justice Dimensions}

Previous studies have reported that the relationship between different dimensions of organizational justice is complex (Colquitt et al., 2001; Skarlicki \& Folger, 1997). Colquitt and his colleagues (2001) assert that the interaction between justice dimensions can improve understanding of how they affect other factors. For example, it is argued that interactional justice can affect perception of distributive justice (Cohen-Charash \& Spector, 2001) and that the interaction may impact other outcomes, such as organizational commitment (Crow et al., 2012). In other words, employees perception of how they receive fair outcomes depend on their perceptions of how they feel the process of the organization and their relationship with their supervisors are fair (Brockner, 2002; Brockner et al., 2008; Colquitt et al., 2001; Leng et al., 2001). It is also found that employees' view on how they feel the procedure of an organization is fair is affected by their relationship with their supervisors (Wang, Liao, Xia, \& Chang, 2010). Recent studies found that interactions between dimensions of justice, such as procedural, interactional, and distributive justice, may influence both personal and organizational outcomes (Abu Elanain, 2010a; Crow et al., 2012; Wang et al., 2010).

Accordingly, this study hypothesized that interactional justice is positively and significantly related to procedural and distributive justice in the UAE. Moreover, the study predicted that procedural justice mediates the links between interactional justice and distributive justice. Thus: 
H1: Interactional justice is positively associated with procedural justice.

H2: Interactional justice is positively associated with distributive justice.

H3: $\quad$ Procedural justice is positively associated with distributive justice.

H4: Procedural justice mediates the positive relationship between interactional justice and distributive justice.

\section{Organizational Justice and Organizational Citizenship Behaviors}

The use of organizational justice for promoting organizational citizenship behaviors is a relatively late research interest, even though an extensive amount of empirical research has already been investigated in this area. According to Organ (1990), justice perceptions have a main role in promoting organizational citizenship behaviors. According to Organ (1990), performing employees organizational citizenship behaviors are a response to fair treatment offered by an organization. This is because when employees perceive their working atmosphere is fair, this increases their job satisfaction and in turn prompts them to perform citizenship behavior (Moorman, 1991). There are many studies aimed at understanding the dynamics of the effect of organizational justice on organizational citizenship behaviors. For example, Williams and his colleagues (2002) claim that when employees perceive organizational justice, they have a more positive state of mind, which encourages them to perform organizational citizenship behaviors.

Research constantly shows that there is a positive and strong relationship between organizational justice and organizational citizenship behaviors. Furthermore, many studies have examined this relation directly or indirectly, in a western or non-western context, in the light of overall organizational justice or by using different forms of organizational justice. For example, some researchers (Al-Hyasat et al., 2013; Cohen-Charash \& Spector, 2001; Colquitt et al., 2001; Greenberg, 1993; Niehoff \& Moorman, 1993) have revealed that perceptions of organizational justice are directly related to organizational citizenship behaviors and have an impact on OCB (Young, 2010).

Research findings demonstrate that certain dimensions of justice predict organizational citizenship behaviors better than others. For example, Moorman (1991) found that interactional justice was the best predictor of organizational citizenship behaviors and the only form of organizational justice that was positively related to organizational citizenship behaviors (Farahbod, Azadehdel, Rezaei-Dizgah, \& Nezhadi-Jirdehi, 2012). Some studies that support the association between interactional justice and citizenship behavior have found that interactional justice is a significant predictor of organizational citizenship behaviors (Coyle-Shapiro et al., 2004; Moorman, 1991; Moorman et al., 1993; Williams et al., 2002). Other studies have found that procedural justice is the most deterministic justice influence on organizational citizenship behaviors and is related with types of OCB (Chiaburu \& Lim, 2008; Chiaburu \& Marinova, 2006; Cropanzano, Preha, \& Chen, 2002; Skarlicki \& Folger, 1997), while other studies have indicated that distributive justice is a better predictor of organizational citizenship behaviors, which encourage employees to engage in organizational citizenship behaviors (Ince \& Gül, 2011) and have significant positive impact on organizational citizenship behaviors, directly and indirectly (Haqu \& Aslam, 2011). In view of the above, it was hypothesized that:

H5: Interactional Justice is positively associated with organizational citizenship behaviors.

H6: Procedural Justice is positively associated with organizational citizenship behaviors.

H7: Distributive Justice is positively associated with organizational citizenship behaviors.

\section{Organizational Justice and Turnover Intention}

The relationship between different dimensions of organizational justice and both turnover and turnover intention have been explored by different researchers (Abu Elanain, 2010a; Alexander \& Ruderman, 1987; Loi, Hang-Yue, \& Foley, 2006; Ponnu \& Chuah, 2010). For example, Alexander and Ruderman (1987) examined the effect of organizational justice and six organizational outcomes variables (stress, trust in management, conflict, job satisfaction, turnover intentions, and evaluation of supervisor). The results showed that procedural justice had a stronger relationship with five of the variables than with distributive justice. Furthermore, the results revealed that distributive justice had a stronger relationship with turnover intentions compared with procedural justice. In addition, Ponnu and Chuah (2010) reported that the perceptions of distributive and procedural justice were 
significantly correlated to turnover intention. These results also supported the results of Dailey and Kirk's (1992) study which considered the opposite relationship between procedural justice and intention to quit as one of withdrawal strategy. Furthermore, recent meta-analyses has provided evidence of the link between procedural justice with intention to quit in different types of organizations (Cohen-Charash \& Spector, 2001; Colquitt et al., 2001). Based on the numerous studies mentioned earlier, this study expected that the three forms of organizational justice are negatively correlated to turnover intention.

Therefore, this study predicted that the three dimensions of organizational justice (distributive, procedural, and interactional justice) would be related to turnover intention. Thus:

H10: Interactional justice is negatively associated with turnover intention.

H11: Procedural justice is negatively associated with turnover intention.

H12: Distributive justice is negatively associated with turnover intention.

\section{The Mediating Effects of Procedural Justice and Distributive Justice}

Recent research found that organizational justice dimensions mediate some of the relationships that could impact organizational citizenship behaviors and turnover intention.

In a non-Arab context, Zhang and Agarwal (2009) examined the mediating effect of three types of organizational justice (distributive, procedural, and interactional) on human resources practices (empowerment, psychological contract fulfillment, and communication) and organizational citizenship behaviors and turnover intention. The findings showed that all types of organizational justice impact organizational citizenship behaviors positively, while only distributive and interactional justice impact turnover intention and play a mediating role between the independent and dependent variables (Zhang \& Agarwal, 2009). In Cyprus, Nadiri and Tanova (2010) investigated the effect of organizational justice perceptions (distributive, procedural, and interactional justice) of hotel employees with job satisfaction, OCB, and turnover intention. Their study found that distributive justice was the stronger predictor of all various work related variables (job satisfaction, OCB, and turnover intention) than procedural justice.

In the context of the UAE, Abu Elanian (2009, 2010a, 2010b) conducted studies that examined the role of organizational justice dimensions as mediator of different variables in the context of the UAE. For example, Abu Elanian (2008) investigated the influence of job characteristics on work attitudes and behaviors (e.g., turnover intention) and tested mediating roles of distributive justice on the job characteristics-work outcomes relationship. The results showed that distributive justice mediates some of the links of job characteristics-work outcomes (i.e., task identity and turnover intentions, skill variety and turnover intentions). Abu Elanian (2010a) also examined the impact of procedural justice on work outcomes and tested the mediating influence of distributive justice as a mediator between these relationships. The results of the study revealed that procedural justice is more strongly related to organizational commitment and job satisfaction than distributive justice. Moreover, the result showed that distributive justice plays a role in mediating some of the relationships between procedural justice and work outcomes. Another study conducted by Abu Elanain (2010b) assessed the effect of openness to experience on organizational citizenship behavior dimensions and investigated to what extent work locus of control and interactional justice mediate the relationship between openness and OCB dimensions. The findings reveal that interactional justice successfully plays a role in mediating the influence of openness to experience on OCB dimensions.

Consistent with the current literature, it is hypothesized that both procedural and distributive justice mediate the relationship between interactional justice, organizational citizenship behaviors, and turnover intention:

H8: Procedural justice mediates the positive relationship between interactional justice and organizational citizenship behaviors.

H9: Distributive justice mediates the positive relationship between interactional justice and organizational citizenship behaviors.

H13: Procedural justice mediates the negative relationship between interactional justice and turnover intention.

H14: Distributive justice mediates the negative relationship between interactional justice and turnover intention. 
The study's hypothesized model is depicted in Figure 1, which represents that interactional justice (I.J) influences healthcare employees' organizational citizen behavior (O.C.B), and turnover intention (T.I) in UAE hospitals directly and indirectly. In addition, this study expects that procedural (P.J) and distributive justice (D.J) impacts this relationship when entering as mediators in this relationship.

\section{METHODS}

\section{Data and Sample}

A self-administered English questionnaire containing measures of interactional justice, procedural justice, distributive justice, organizational citizenship behaviors, and turnover intention was used. A total of 500 healthcare employees were randomly selected from three different public hospitals in the UAE and surveyed in order to test the study hypotheses. Anonymity was guaranteed. Overall, 448 respondents completed the questionnaire, for a response rate of 89.6 percent.

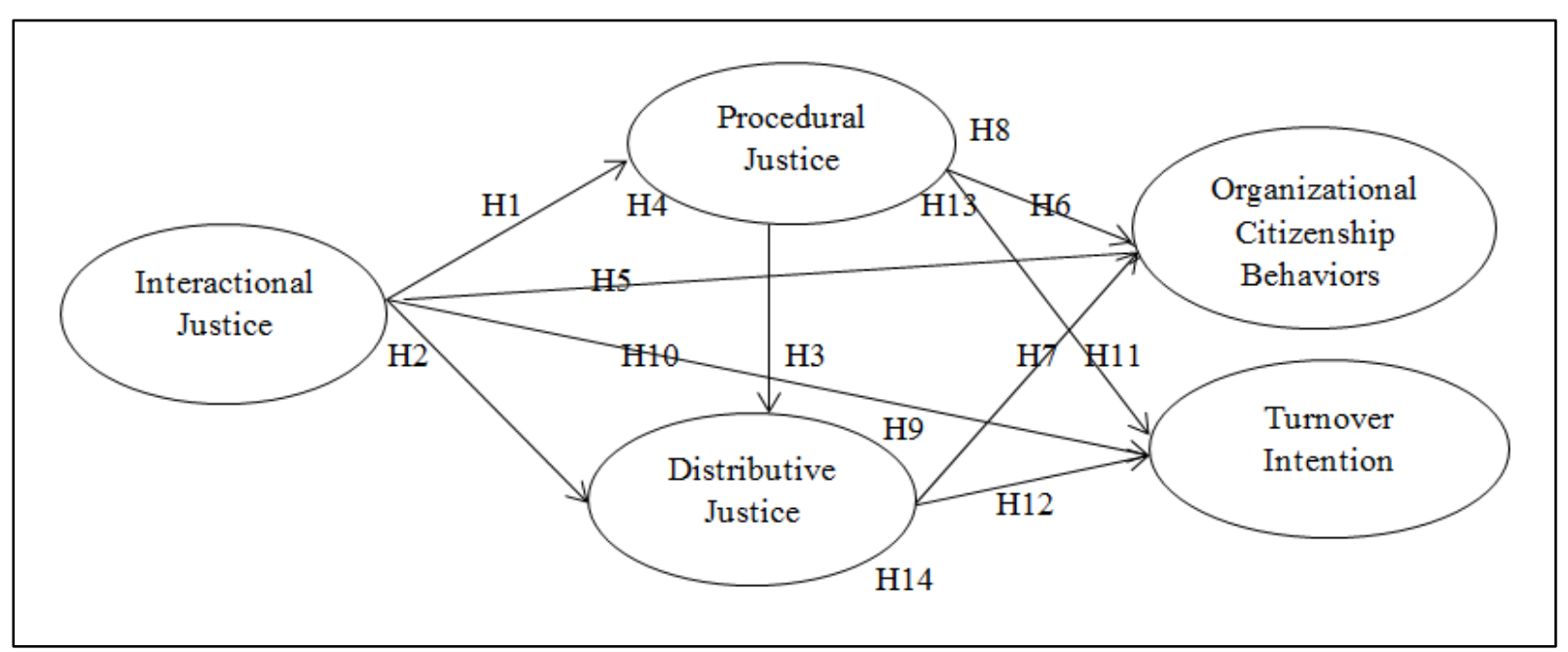

Figure 1: Research Model

As shown in Table 1, 62.1 percent of the respondents were females, most of the respondents were employees (71.7 percent) and 42.3 percent of the respondents were administrators. The average respondent age was 2.6 (SD 0.97) $(2=26-35$ years; $3=36-45$ years $)$ and the respondents had been with the hospital an average of 2.6 years $(\mathrm{SD}=0.88)(2=1-5$ years; $3=6-10$ years years $)$ and had been in their present job 2.4 years $(\mathrm{SD}=.65)(2=1$ 5 years; $3=6-10$ years years).

\section{Measures}

The questionnaire used five-point Likert-type scales (ranging from 1 - strongly disagree to 5 strongly agree) to measure the items of the following constructs:

- Interactional justice measure: Interactional justice was measured using a nine-item scale developed by Niehoff and Moorman (1993) (e.g., "when decisions are made about my job, my manager treats me with kindness and consideration"). The nine items were averaged to form our measures of interactional justice $(\mathrm{M}=3.46, \mathrm{SD}=0.93, \alpha=0.96)$.

- $\quad$ Distributive justice: This was measured by 5-items developed by Niehoff and Moorman (1993). Sample items were: "my work schedule is fair" and "I think that my level of pay is fair." The five items were averaged to form our measures of distributive justice $(\mathrm{M}=3.15, \mathrm{SD}=0.81, \alpha=0.80)$.

- $\quad$ Procedural justice: This construct was measured by six-items developed by Niehoff and Moorman (1993) (i.e., "all job decisions are applied consistently across all affected employees"). The six items were averaged to form our measures of procedural justice $(\mathrm{M}=3.26, \mathrm{SD}=0.91, \alpha=0.91)$. 
- Organization citizenship behavior: Organization citizenship behavior variable was measured with the three-item scale developed by Chen, Hui, and Sego (1998). A sample item from this scale was, "I am always ready to give a helping hand and ready to help those around me." The various items were averaged to form our measures of organization citizenship behaviors $(\mathrm{M}=3.88, \mathrm{SD}=0.80, \alpha=0.86)$.

- $\quad$ Turnover intention: This construct was measured using a three-item scale developed by Cammann et al. (1979). The scale measured the degree to which the participants intend to quit their work. A sample item from this scale was, "I will probably look for a new job in the next year." The various items were averaged to form our measures of turnover intentions $(\mathrm{M}=3.03, \mathrm{SD}=1.22, \alpha=0.91)$.

- Demographic variables: Previous studies have identified numerous demographic variables as correlates of turnover (Tourangeau \& Cranley, 2006) and OCB (Lovel, Aston, Mason, \& Davidson, 1999). Therefore, a series of single statement items was used to assess the respondents' demographics, such as: gender, age, nationality, educational level, and length of service in the hospital, length of service in the current position, managerial level, and job category.

Table 1: Demographic Characteristic of Respondents

\begin{tabular}{|c|c|c|c|}
\hline Demographics & & Frequency & $\%$ \\
\hline \multirow{2}{*}{ Gender } & Male & 170 & 37.9 \\
\hline & Female & 278 & 62.1 \\
\hline \multirow{5}{*}{ Age } & 25 years or less & 24 & 5.4 \\
\hline & 26-35 years & 207 & 46.2 \\
\hline & 36 to 45 years & 125 & 27.9 \\
\hline & 46 to 55 years & 69 & 15.4 \\
\hline & 56 or more & 23 & 5.1 \\
\hline \multirow{2}{*}{ Nationality } & Emirate & 130 & 29 \\
\hline & Non-Emirate & 318 & 71 \\
\hline \multirow{5}{*}{ Educational level } & High school or equivalent & 44 & 9.8 \\
\hline & Diploma or technical school & 102 & 22.8 \\
\hline & Bachelor's degree & 200 & 44.6 \\
\hline & Master's degree & 77 & 17.2 \\
\hline & Doctoral degree & 25 & 5.6 \\
\hline \multirow{4}{*}{ Years in current hospital } & Less than one year & 32 & 7.1 \\
\hline & $1-5$ years & 194 & 43.3 \\
\hline & $6-10$ years & 123 & 27.5 \\
\hline & More than 10 years & 99 & 22.1 \\
\hline \multirow{4}{*}{ Years in current position } & Less than one year & 45 & 10 \\
\hline & $1-5$ years & 232 & 51.8 \\
\hline & $6-10$ years & 97 & 21.7 \\
\hline & More than 10 years & 74 & 16.5 \\
\hline \multirow{3}{*}{ Job position } & Manager & 42 & 9.3 \\
\hline & Supervisor & 85 & 19 \\
\hline & Employee & 321 & 71.7 \\
\hline \multirow{6}{*}{ Job categories } & Nurses & 125 & 28 \\
\hline & Doctors & 40 & 9 \\
\hline & Technicians & 39 & 8.7 \\
\hline & Pharmacist & 19 & 4.2 \\
\hline & Administrators & 190 & 42.3 \\
\hline & Other & 35 & 7.8 \\
\hline
\end{tabular}

\section{Analytical Strategy}

The data was analyzed to assess the main hypothesis of the relationship between organizational justice (interactional, procedural, and distributive justice), organizational citizenship behaviors, and turnover intention. Multiple techniques have been used to explore data that qualify relationships among variables. Hierarchal regression analysis use statistical procedures suggested by Baron and Kenny (1986).

According to Baron and Kenny (1986), testing mediation includes three steps. First, the independent variable affects the dependent variable. Second, the independent variable affects the mediating variable. Third, the 
mediating variable affects the dependent variable. Finally, there is full mediation when the inclusion of the mediator variable into the second regression equation of the previous step completely eliminates the effects of the independent variable on dependent variable and there is a significant relationship between the mediating variable and dependent variable. Partial mediation exists when the inclusion of the mediator reduces the effect of independent variable on dependent variable and there is a significant relationship between the mediating variable and dependent variable.

\section{RESULTS}

\section{Measurement Characteristic}

Since the scales were submitted to a new sample, exploratory factor analysis was performed for each scale separately as indicated in Table 2. Principal factor with varimax rotation was used for each variable to demonstrate the factor structure. The study used the coefficient alpha to estimate reliability for scales. The exploratory factor analysis for interactional, procedural, distributive justice, organizational citizenship behaviors, and turnover intention revealed a one-factor structure for each one of them. Alpha reliability for interactional justice was 0.96 , for procedural justice 0.91 , for distributive justice 0.80 , for organizational citizenship behaviors 0.86 , and for turnover intentions 0.91 . Factor loadings of items varied from 0.64 to 0.95 . Moreover, means and standard deviations for each variable were calculated and a correlation matrix of all variables used in the study was created.

Means, standard deviations, and inter-correlations between variables are presented in Table 3. As shown, the three dimensions of organizational justice are correlated positively as estimated (all significant at $\mathrm{p}<0.001$ ). This evidences a high level of systematic variance and discriminate validity. In addition, these dimensions have significant relationships with both organizational citizenship behaviors and turnover intention. Distributive, procedural, and interactional justice have positive relationship with organizational citizenship behaviors $(r=0.28$, $0.38,0.37$, respectively, all $\mathrm{p}<0.001)$ and negative relationship between distributive $(r=-0.42, p<0.001)$, interactional justice $(r=-0.37, p<0.001)$, and procedural justice $(r=-0.40, p<0.01)$ with turnover intention. These results support the study hypotheses and in a direction consistent with previous theory and studies mentioned earlier in the literature.

In terms of linear effects, hierarchical regression analysis indicated that interactional justice successfully predicted procedural and distributive justice. It explained an average of 38 percent and 72 percent of the variance in procedural justice and distributive justice, respectively. Interactional justice had significant functional influence on procedural justice $(B=0.85, \mathrm{P}<.001)$ and distributive justice $(B=0.54, \mathrm{P}<.001)$. Also, the result showed that procedural justice had significant functional influence on distributive justice $(B=0.60, \mathrm{P}<.001)$. The findings of the study are aligned with the previous findings between interactional justice and procedural justice (Wang et al., 2010), interactional justice and distributive justice (Cohen-Charash \& Spector, 2001) and procedural justice and distributive justice (Abu Elanain, 2010a). Thus, Hypotheses 1, 2, and 3 were accepted.

Furthermore, hierarchical regression analysis indicated that the three organizational justice dimensions successfully predicted organizational citizenship behaviors and turnover intention. Interactional and procedural justice explained an average of 0.15 percent, interactional and distributive justice explained an average of 0.15 percent of the variance in $\mathrm{OCB}$, respectively (see Tables 4 and 5). Interactional, procedural and distributive justice appeared to enhance OCB significantly $(\mathrm{B}=0.37, \mathrm{P}<.001, \mathrm{~B}=0.38, \mathrm{P}<.001, \mathrm{~B}=0.28, \mathrm{P}<.001)$. In contrast, interactional justice, procedural, and distributive justice $(\mathrm{B}=-0.37, \mathrm{P}<.001, \mathrm{~B}=-0.40, \mathrm{P}<.01, \mathrm{~B}=-0.42, \mathrm{P}<$ .001 ) had significant functional affects by reducing turnover intention and turnover intention. Interactional and procedural justice explained an average of 0.16 percent and interactional and distributive justice explained an average of 0.20 percent of the variance in turnover intention, respectively, thus, Hypothesis 5, 6, 7, 10, 11, and 12 were supported. 
Table 2: Exploratory Factor Analysis and Reliability Results

\begin{tabular}{|c|c|c|c|c|c|}
\hline Factors & Items & Factor Loading & Eigenvalue & Percentage of Variance & Cronbach \\
\hline \multirow{5}{*}{ Distributive Justice } & 1 & 0.70 & \multirow{5}{*}{0.80} & \multirow{5}{*}{56.38} & \multirow{5}{*}{2.82} \\
\hline & 2 & 0.68 & & & \\
\hline & 3 & 0.79 & & & \\
\hline & 4 & 0.77 & & & \\
\hline & 5 & 0.80 & & & \\
\hline \multirow{6}{*}{ Procedural Justice } & 1 & 0.78 & \multirow{6}{*}{0.91} & \multirow{6}{*}{69.35} & \multirow{6}{*}{4.16} \\
\hline & 2 & 0.89 & & & \\
\hline & 3 & 0.87 & & & \\
\hline & 4 & 0.86 & & & \\
\hline & 5 & 0.79 & & & \\
\hline & 6 & 0.81 & & & \\
\hline \multirow{9}{*}{ Interactional Justice } & 1 & 0.87 & \multirow{9}{*}{0.96} & \multirow{9}{*}{74.41} & \multirow{9}{*}{6.70} \\
\hline & 2 & 0.81 & & & \\
\hline & 3 & 0.80 & & & \\
\hline & 4 & 0.88 & & & \\
\hline & 5 & 0.90 & & & \\
\hline & 6 & 0.88 & & & \\
\hline & 7 & 0.89 & & & \\
\hline & 8 & 0.88 & & & \\
\hline & 9 & 0.87 & & & \\
\hline \multirow{3}{*}{ OCB } & 1 & 0.92 & \multirow{3}{*}{0.86} & \multirow{3}{*}{78.67} & \multirow{3}{*}{2.36} \\
\hline & 2 & 0.91 & & & \\
\hline & 3 & 0.82 & & & \\
\hline \multirow{3}{*}{ Turnover Intention } & 1 & 0.95 & \multirow{3}{*}{0.91} & \multirow{3}{*}{84.97} & \multirow{3}{*}{2.55} \\
\hline & 2 & 0.95 & & & \\
\hline & 3 & 0.86 & & & \\
\hline
\end{tabular}

Table 3: Means, Standard Deviations, and Inter-Correlations among Variables

\begin{tabular}{|c|c|c|c|c|c|c|c|}
\hline & $\mathbf{M}$ & S.D. & 1 & 2 & 3 & 4 & 5 \\
\hline 1 & 3.15 & 0.81 & 1 & & & & \\
\hline 2 & 3.26 & 0.91 & $0.60 * * *$ & 1 & & & \\
\hline 3 & 3.46 & 0.93 & $0.54 * * *$ & $0.85 * * *$ & 1 & & \\
\hline 4 & 3.88 & 0.80 & $0.28 * * *$ & $0.38 * * *$ & $0.37 * * *$ & 1 & \\
\hline 5 & 3.03 & 1.22 & $-0.42 * * *$ & $-0.40 * *$ & $-0.37 * * *$ & $-0.16 * * *$ & 1 \\
\hline
\end{tabular}

Notes: ** $\mathrm{P}<.01, * * * \mathrm{P}<.001$, all two-tailed tests, 1 (Distributive Justice), 2 (Procedural Justice), 3 (Interactional Justice), 4 (OCB), 5 (Turnover Intention)

The results of the study are aligned with the previous findings between organizational justice and OCB (Abu Elanain, 2010; Al-Hyasat et al., 2013; Chegini, 2009; Williams et al., 2002; Young, 2010) and organizational justice and turnover intention (Abu Elanain, 2010a; Alexander \& Ruderman, 1987; Hassan \& Hashim, 2011; Loi et al., 2006; Ponnu \& Chuah, 2010).

The role of procedural justice as a mediator variable in the interactional justice-distributive justice, interactional justice-organizational citizenship behaviors, and interactional justice-turnover intention relationships was tested using a statistical procedure suggested by Baron and Kenny (1986). The regression analyses to test for mediation effect of procedural justice are presented in Table 4. As can be seen in Table 4, interactional justice explanation was significantly and positively related to procedural justice $(\mathrm{B}=0.85, \mathrm{P}<.001)$, thus providing support for the first condition (there is a significant relationship between independent and mediator variable). Also, interactional justice explanation was significantly and positively related to distributive justice and OCB, respectively, $(\mathrm{B}=0.54, \mathrm{P}<.001 ; \mathrm{B}=0.37, \mathrm{P}<.001)$ and significantly and negatively related to turnover intention $(\mathrm{B}=-0.37,<.001)$. This result provided support for the second condition (there is a significant relationship between independent and dependent variables).

The results also indicated that procedural justice had a significant positive relationship with $\mathrm{OCB}(\mathrm{B}=$ $0.38, \mathrm{P}<.001)$ and when procedural justice was included with the interactional justice-OCB regression model, 
regression coefficient of interactional justice, and OCB reduced from $.37, \mathrm{P}<.001$ to $.18, \mathrm{P}<.05$. This demonstrated that procedural justice partially mediated the relationship between interactional justice and OCB. Similarly, when procedural justice was included the interactional-distributive justice regression model, procedural justice had a significant positive relationship with distributive justice $(B=0.54, P<.001)$ and the effect of interactional justice became insignificant $(\mathrm{B}=.10)$. This demonstrated that procedural justice fully mediated the relationship between interactional justice and distributive justice. Moreover, when procedural justice was included with interactional justice-turnover intention relationship, the results showed that procedural justice remained significantly related to turnover intention, but interactional justice was no longer a significant predictor turnover intention. Thus, the study Hypotheses H4, and H13 were fully supported and H8 partially supported.

Table 4: Results for Hierarchical Regression Testing the Mediating Effect of Procedural Justice

\begin{tabular}{|l|c|c|c|c|c|c|c|}
\hline \multicolumn{1}{|c|}{ Predictors } & \multicolumn{9}{c|}{ Criterion Variables } \\
\hline & $\begin{array}{c}\text { Procedural } \\
\text { Justice }\end{array}$ & $\begin{array}{c}\text { Distributive } \\
\text { Justice }\end{array}$ & $\begin{array}{c}\text { Distributive } \\
\text { Justice }\end{array}$ & OCB & OCB & $\begin{array}{c}\text { Turnover } \\
\text { Intention }\end{array}$ & $\begin{array}{c}\text { Turnover } \\
\text { Intention }\end{array}$ \\
\hline Step 1 & & & & & & & \\
\hline Procedural Justice & & $0.60 * * *$ & & $0.38^{* * *}$ & & $-0.40^{* *}$ & \\
\hline Interactional Justice & $0.85^{* * *}$ & & $0.54 * * *$ & & $0.37 * * *$ & $-0.37 * *$ \\
\hline R2 & 0.72 & 0.37 & 0.29 & .014 & 0.14 & 0.16 & 0.13 \\
\hline Step 2 & & & & & & & $-0.33^{* * *}$ \\
\hline Procedural Justice & & & $0.52 * * *$ & & $0.22^{* *}$ & & -0.09 \\
\hline Interactional Justice & & & 0.10 & & $0.18 *$ & & 0.16 \\
\hline R2 & & & 0.38 & & 0.15 & & 0.03 \\
\hline$\Delta R^{2}$ & & & 0.08 & & 0.01 & & 16.14 \\
\hline F for $\Delta R^{2}$ (Step 1 \& 2) & & & $52.70 * * *$ & & $6.90 * *$ & & \\
\hline
\end{tabular}

Notes: $* \mathrm{P}<.05, * * \mathrm{P}<.01, * * * \mathrm{P}<.001$ (standardized regression coefficients are reported) $\mathrm{N}=448$

The regression analyses to test for mediation effect of distributive justice are presented in Table 5. The results showed that interactional justice explanation was significantly and positively related to distributive justice (B $=0.54, \mathrm{P}<.001)$, thus providing support for the first condition. Also, interactional justice explanation was significantly and positively related to distributive justice and $\mathrm{OCB}$, respectively, $(\mathrm{B}=0.54, \mathrm{P}<.001 ; \mathrm{B}=0.37, \mathrm{P}<$ $.001)$ and significantly and negatively related to turnover intention $(\mathrm{B}=-0.37, \mathrm{P}<.001)$, which also supports the second and the third condition. Furthermore, distributive justice had a significant positive relationship with OCB (B $=0.28, \mathrm{P}<.001)$ and when it was included with the interactional justice-OCB regression model, the regression coefficient of interactional justice and OCB was reduced from $.37, \mathrm{P}<.001$ to $.31, \mathrm{P}<.001$. This demonstrated that distributive justice partially mediated the relationship between interactional justice and OCB. The results also showed that distributive justice partially mediated the relationship between interactional justice and turnover intention, where distributive justice remained significantly related to turnover intention and interactional justice effects was reduced from $-0.37 \mathrm{P}<.001$ to $-0.20 \mathrm{P}<.001$.Thus, the study hypotheses $\mathrm{H} 9$, and H14 were partially supported.

Table 5: Results for Hierarchical Regression Testing the Mediating Effect of Distributive Justice

\begin{tabular}{|l|c|c|c|c|c|}
\hline \multicolumn{1}{|c|}{ Predictors } & \multicolumn{5}{|c|}{ Criterion Variables } \\
\hline Step 1 & Distributive Justice & OCB & OCB & Turnover Intention & Turnover Intention \\
\hline Distributive Justice & & & & & \\
\hline Interactional Justice & $0.85^{* * *}$ & $0.28^{* * *}$ & & $-0.42^{* * *}$ & \\
\hline R2 & 0.72 & 0.08 & 0.14 & 0.18 & $-0.37 * * *$ \\
\hline Step 2 & & & & & 0.13 \\
\hline Distributive Justice & & & $0.11 *$ & & $-0.31^{* * *}$ \\
\hline Interactional Justice & & & 0.15 & & $-0.20^{* * *}$ \\
\hline R2 & & & 0.01 & & 0.20 \\
\hline$\Delta R^{2}$ & & & $4.41^{*}$ & & 0.07 \\
\hline F for $\Delta \mathrm{R}^{2}$ (Step 1 \& 2) & & & & $38.55^{* * *}$ \\
\hline
\end{tabular}

Notes: $* \mathrm{P}<.05, * * \mathrm{P}<.01, * * * \mathrm{P}<.001$ (standardized regression coefficients are reported) $\mathrm{N}=448$ 


\section{DISCUSSION}

The current study focused on exploring the impact of procedural and distributive justice as mediators of the relationships between interactional justice and work related variables. Few studies focus on investigating these relationships in a non-western context, especially in the UAE. Therefore, the goal of this study was to address these gaps by conducting this research in an important sector of the UAE, the healthcare sector. This research is one of the first empirical studies of its kind to demonstrate the role of procedural and distributive justice as mediators between interactional justice and employee work attitudes and behaviors in the UAE.

The current study showed that the overall organizational justice perception (interactional, procedural, and distributive justice) is positively and significantly related to organizational citizenship behaviors. Also, the results revealed that procedural justice is the strongest variable in predicting organizational citizenship behaviors, followed by interactional justice and then distributive justice. These empirical results are in line with previous work that suggests procedural justice (Chiaburu \& Lim, 2008; Chiaburu \& Marinova, 2006; Cropanzano et al., 2002; Skarlicki \& Folger, 1997) and interactional justice are potentially important determinants of organizational citizenship behaviors (Coyle-Shapiro et al., 2004; Moorman, 1991; Moorman et al., 1993; Williams et al., 2002). One possible explanation for these findings is that employees who tend to show positive feelings towards organizational justice are likely to engage in more organizational citizenship behaviors (e.g., when employees work harder, communicate with others in the workplace to increase individual and group performance, and obey their organizations' rules), which in turn improves their organizational performance. Also, the study results are consistent with prior studies that found a strong relationship between organizational justice and organizational citizenship behaviors (Abu Elanain, 2010; Al-Hyasat et al., 2013; Chegini, 2009; Williams et al., 2002; Young, 2010). Additionally, the study results are consistent with a number of other studies' results that showed negative relationship between organizational justice and turnover intention (Abu Elanain, 2010a; Alexander \& Ruderman, 1987; Dailey \& Kirk, 1992; Hassan \& Hashim, 2011; Loi et al., 2006; Ponnu \& Chuah, 2010). Moreover, the results indicated that organizational justice has both significant and negative impact on employees' turnover intention in the healthcare sector. The study found that distributive justice is the strongest predictor of turnover intention followed by procedural justice and then interactional justice. These findings are consistent with findings of previous past studies (e.g., Hemdi \& Nasurdin, 2008; Nadiri \& Tanova, 2010).

The study examined the indirect relationship between interactional justice, organizational citizenship behaviors, and turnover intention by using procedural and distributive justice as mediators between these relationships. The findings provided strong empirical support for the research hypothesis that the impact of interactional justice on organizational citizenship behaviors and turnover intention can occur directly or indirectly when procedural and distributive justice act as mediators.

In order to test the mediating role of procedural and distributive justice on interactional-organizational citizenship behaviors and turnover intention link, this study first looked at the interactional justice-procedural and distributive justice relationships. The results showed that employee perceptions about interactional justice might affect the perceptions of employees of procedural and distributive justice. The relationships between interactional justice perceptions were positively and significantly related to procedural and distributive justice. Moreover, the research findings indicated that healthcare employees who tend to show positive feelings towards interactional justice are likely to report positive feelings towards procedural and distributive justice. In other words, the findings of the current research suggested that when healthcare employees perceive they receive quality treatment from their supervisors, they will likely perceive the procedural and polices that are implemented by the organization and the outcomes they receive are fair. Hence, healthcare employees who tend to show positive feelings towards interactional justice are more likely to report higher levels of procedural and distributive justice and, consequently, will be encouraged to engage in organizational citizenship behaviors and more willing to remain in the organization.

Obtained results indicate that the organizational justice dimensions' relationship with each other support the role of social exchange theory (Blau, 1964) in which employees' views on how they feel the fairness of outcomes they receive and procedures adopted by the organization are affected by their relationship with their supervisors or managers. This finding is in line with some of the previous studies (Bies \& Moag, 1986; Brockner, 2002; Brockner et al., 2008; Cohen-Charash \& Spector, 2001; Colquitt et al., 2001; Greenberg, 1993; Leng et al., 2001; Wang et al., 2010). 
In addition, the current study found that procedural justice positively and significantly impact distributive justice, supporting the procedural primary model discussed by Sweeney and McFarlin (1993) which describes the relationship between procedural and distributive justice and its impact on employee attitudes and behavior. This result is consistent with the results of Abu Elanain's study (2010a) in which he used distributive justice as a mediator between procedural justice and work outcome.

The current study also showed that procedural and distributive justice partially mediated the relationship between interactional justice and OCB. The effects of interactional justice on turnover intention decreased to insignificant levels when procedural justice was added to the equation as an antecedent of turnover intention. Thus, procedural justice fully mediated the relationship between organizational justice and turnover intention. Furthermore, the results revealed that the influence of interactional justice on turnover intention decreased but remained significant when distributive justice acted as a mediator between them. Therefore, distributive justice partially mediates the relationship between interactional justice and OCB.

\section{MANAGERIAL IMPLICATIONS AND CONTRIBUTIONS}

The study's findings provide both theoretical and practical implications. This study adds to our understanding of the antecedents of OCB and turnover intentions. It has some important contributions. First, and the most unique contribution of this study, is it was the first study in the UAE and the Middle East that investigated the link between organizational justice, organizational citizenship behaviors, and turnover intention of healthcare employees by using two dimensions of organizational justice (procedural and distributive justice) as mediators between interactional justice, organizational citizenship behaviors, and turnover intention. So, this study contributes to the understanding of the effects of organizational justice on both organizational citizenship behaviors and turnover intention across the region. In fact, examining the influence of organizational justice, especially in empirical studies in the healthcare sector and in the UAE context, is also rare, so this study contributes to the literature on this topic. Second, this study not only empirically indicates the significant role of organizational justice on enhancing organizational citizenship behaviors and reducing employees' turnover intention in a non-western context, but also reveals the nature of this link directly and indirectly through the mediating role of procedural and distributive justice. It is one of the first empirical studies of its kind to demonstrate the role of procedural and distributive justice as mediators between interactional justice and employee work attitudes and behaviors.

This study has practical implications from a managerial point of view and could increase management's understanding of organizational citizenship behaviors and employee turnover intention in order to operate efficiently. Moreover, it indicates that management should pay attention to HR strategies to prevent employee turnover and to promote organizational citizenship behaviors. Management should enhance organizational justice by integrating this concept in their strategic thinking and actions so as to improve the level of employee organizational citizenship behaviors and reduce employee turnover intention. For example, management should pay attention to providing adequate fairness in terms of formal procedures, reward allocation, and interpersonal treatment when making policy or implementing rules and regulations. As suggested by Abu Elanain (2010b), managers and supervisors in the UAE should take appropriate actions that support provisions of interactional justice when managing their employees, such as communicating effectively with their employees. In other words, when managers and supervisors communicate effectively with their employees, this influences the employees' perceptions that their managers are treating them fairly, and this encourages them to promote organizational citizenship behaviors and they are less inclined to leave their jobs. In contrast, when employees perceive that their managers or supervisors are treating them unfairly, then they will exhibit fewer organizational citizenship behaviors and will tend them to leave their organizations. Therefore, enhancing organizational justice could have practical reach that ultimately improves employee retention and promotes organizational citizenship behaviors (Abu Elanain, 2010b).

Furthermore, the results of this study suggest that interactional justice has a key role on influencing dependent variables of the study. Therefore, this study has other implications for organizational training programs. For instance, the importance of training managers and supervisors about interactional justice and its impact on employees' perceptions and how it fosters a positive employee-organization relationship could be emphasized. 


\section{LIMITATIONS AND FUTURE RESEARCH DIRECTIONS}

As with any study, this study has some limitations that suggest areas for future research directions. Firstly, the results were derived from a cross-sectional research design, which cannot confirm the direction of causality among variables of this study. Secondly, limitations were related to the sample of this research, which was collected from one sector, the healthcare sector, and only gathered from public hospitals in UAE. Therefore, this setting may limit the generalizability of the study's finding. Finally, this study used self-report measures of organizational citizenship behaviors collected from employees, not from supervisors of the respondents.

In light of the above limitations of this study, there are some suggestions for future research. First, future research could look at the relationship between organizational justice, organizational citizenship behaviors, and turnover intention by using other mediators such as empowerment and participation in decision making. Second, another area for future research could be exploring the impact of culture on employees' perceptions of organizational justice and its effect on organizational citizenship behaviors and turnover intention. Third, future studies are also needed to conduct a cross-cultural empirical studies that could provide a lesson to managers who work in a multicultural context on how perception of organizational justice could affect employee turnover intention. Fourth, future research could also cover samples from public and private hospitals or from other industry sectors, as these could provide more meaningful results and could be generalized to the UAE context. Fifth, it is suggested that future research in this area should be conducted by using organizational citizenship behaviors data based on supervisory ratings of employees. Finally, conducting a longitudinal study to examine the possible directional relationship of the study's variables is proposed for future research.

\section{CONCLUSION}

In conclusion, the results of this study suggest that organizational justice plays a prominent role and significantly promotes organizational citizenship behaviors and significantly reduces turnover intention of healthcare employees. Also, this study presents empirical evidence that procedural and distributive justice fully/partially mediates the relationship between interactional justice, organizational citizenship behaviors, and turnover intention of healthcare employees. The results of this study contribute to the literature on organizational justice and employees' attitude and behavior in a non-western context, the UAE. More specifically this study enhances and supports the findings of previous research regarding the role of procedural and distributive justice as mediator variables.

\section{AUTHOR INFORMATION}

Thamna Salem Al Afari is a DBA Candidate in Business Administration at Abu Dhabi University, United Arab Emirates. She received her MBA from Ajman University, United Arab Emirates in 2009. Her research interests include organizational behavior, human resource management, and leadership. Thamna S. Al Afari, DBA Candidate, College of Business Administration, Abu Dhabi University, Post Box No: 78050, Abu Dhabi, United Arab Emirates.

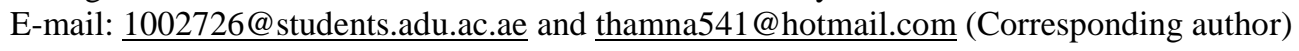

Hossam Mohammed Abu Elanain joined the College of Business Administration at University of Abu Dhabi as an Associate Professor of Management in 2009. Prior to that, he was the Chair of the Management Department at University of Dubai. His teaching interests are in management and organizational behavior, leadership, change management, human resources management, and business negotiating skills. Dr. Abu Elanain research interests focus on leadership, emotional intelligence, personality and performance, organizational citizenship behavior, organizational justice and performance, and job design. His research papers have been published in international refereed journals such as Journal of Management Development, Cross Culture Management: An International Journal, and Sam Advanced Management Journal. He also participated and presented his research papers in several international conferences. Hossam M. Abu Elanain, Ph.D., Associate Professor of Management, Department of Management, College of Business Administration, Abu Dhabi University, P.O. Box: 59911, Abu Dhabi, United Arab Emirates. E-mail: hossam.elanain@adu.ac.ae 


\section{REFERENCES}

1. Abu Elanain, H. M. (2010a). Testing the direct and indirect relationship between organizational justice and work outcomes in a non-western context of the UAE. Journal of Management Development, 29(1), 5-27.

2. Abu Elanain, H. M. (2010b). Work locus of control and interactional justice as mediators of the relationship between openness to experience and organizational citizenship behaviors. Cross Cultural Management: An International Journal, 17(2), 170-192.

3. Abu Elanain, H. M. (2009). Job characteristics, work attitudes and behaviors in a non-western context: Distributive justice as a mediator. Journal of Management Development, 28(5), 457-477.

4. Adams, J. S. (1965). Inequity in social exchange. In L. Berkowitz (Ed.), Advances in experimental social psychology. New York, NY: Academic Press.

5. Albrecht, S. L., \& Andreetta, M. (2011). The influence of empowering leadership, empowerment and engagement on affective commitment and turnover intentions in community health. Leadership in Health Service, 24(3), 228- 237.

6. Alexander, S., \& Ruderman, M. (1987). The role of procedural and distributive justice in organization behavior. Social Justice Research, 1(2), 177-198.

7. Al-Hyasat, Al Shra'ah, \& Abu Rumman. (2013). The impact of the organizational justice on the development of the organizational citizenship behaviors in Jordanian press organizations. European Journal of Business and Management, 5(2), 213-222.

8. Arthaud-Day, M. L., Rode, J. C., \& Turnley, W. H. (2012). Direct and contextual effects of individual values on organizational citizenship behaviors in teams. Journal of Applied Psychology, 97(4), 792-807.

9. Azeem, S. M. (2010). Job satisfaction and organizational commitment among employees in the sultanate of Oman. Psychology, 1(4), 295-299.

10. Bagtasos, M. R. (2011). Quality of work life: A review of literature. DLSU Business and Economics Review, 20(2), 1-8.

11. Bakhshi, A., Kumar, K., \& Rani, E. (2009). Organizational justice perceptions as predictor of job satisfaction and organization commitment. International Journal of Business and Management, 4(9), 145 154.

12. Baron, R. M., \& Keny, D. A. (1986). The moderator-mediator variable distinction in social psychological research: Conceptual, strategic, and statistical consideration, Journal of Personality and Social Psychology, 51, 1173-82.

13. Benjamin, A. (2012). Human resource development climate as a predictor of citizenship behaviour and voluntary turnover intentions in the banking sector. International Business Research, 5(1), 110-119.

14. Bies, R. J., \& Moag, J. S. (1986). Interactional justice: communications criteria of fairness. In R. J. Lewicki, B. H. Sheppard, \& M. H. Bazerman (Eds.), Research on negotiation in organizations (vol. 1, pp. 43-55). Greenwich, CT: JAI Press.

15. Blau, P. (1964). Exchange and power in social life. New York: Wiley.

16. Brewer, C. S., Kovner, C. T., Greene, W., Tukov-Shuser, M., \& Djukic, M. (2012). Predictors of actual turnover in a national sample of newly licensed registered nurses employed in hospitals. Journal of Advanced Nursing, 68(3), 521-538.

17. Brockner, J., De Cremer, D., Fishman, A. Y., \& Spiegel, S. (2008). When does high procedural fairness reduce self-evaluations following unfavorable outcomes? The moderating effect of prevention focus. Journal of Experimental Social Psychology, 44, 187-200.

18. Brockner, J. (2002). Making sense of procedural justice: how high procedural fairness can reduce or heighten the influence of outcome favorability. Academy of Management Review, 27, 58-76.

19. Cammann, C., Fichman, M., Jenkins, D., \& Klesh, J. (1979). The Michigan organizational assessment questionnaire. (Unpublished manuscript). University of Michigan, Ann Arbor.

20. Cascio, W. F. (2006). Managing human resources: productivity, quality of work life, profits (7th ed.). Burr Ridge, Ill: McGraw-Hill.

21. Chegini, M. G. (2009). The relationship between organizational justice and organizational citizenship behaviors. American Journal of Economics and Business Administration, 1(2), 171-174.

22. Chen, X. P., Hui, C., \& Sego, D. J. (1998). The role of organizational citizenship behaviors in turnover: Conceptualization and preliminary tests of key hypotheses. Journal of Applied Psychology, 83(6), 922-931. 
23. Cheung, M. (2013).The mediating role of perceived organizational support in the effects of interpersonal and informational justice on organizational citizenship behaviors. Leadership and Organization Development Journal, 34(6), 551-572.

24. Chiaburu, D., \& Lim, A. (2008). Manager trustworthiness or interactional justice? Predicting organizational citizenship behaviors. Journal of Business Ethics, 83, 453-467.

25. Chiaburu, D. S., \& Marinova, S. V. (2006). Employee role enlargement: interactions of trust and organizational fairness. Leadership and Organization Development Journal, 27, 168-182.

26. Cloninger, P., Ramamoorthy, N., \& Flood, P. (2011). The influence of equity, equality and gender on organizational citizenship behaviors. SAM Advanced Management Journal, 76(4), 37-46.

27. Cohen-Charash, Y., \& Spector, P. E. (2001). The role of justice in organizations: A meta-analysis. Organizational Behavior and Human Decision Processes, 86(2), 278-321.

28. Colquitt, J. A., Conlon, D. E., Wesson, M. J., Porter, C. O. L. H., \& Ng, K. Y. (2001). Justice at the millennium: A meta-analytic review of 25 years of organizational justice research. Journal of Applied Psychology, 86, 425-445.

29. Colquitt, J. A., Greenberg, J., \& Zapata-Phelan, C. P. (2005). What is organizational justice?: A historical overview. In J. Greenberg \& J. A. Colquitt (Eds.), The handbook of organizational justice (pp. 3-56). Mahwah, NJ: Erlbaum.

30. Colquitt, J. A., Scott, B. A., Judge, T. A., \& Shaw, J. C. (2006). Justice and personality: Using integrative theories to derive moderators of justice effects. Organizational Behavior and Human Decision Process, 100, 110-127.

31. Coyle-Shapiro, J., Kessler, J., \& Purcell, J. (2004). Exploring organizationally directed citizenship behaviour: reciprocity or 'It's my Job'? Journal of Management Studies, 41(1), 85-106.

32. Cropanzano, R., Prehar, C., \& Chen, P (2002) Using social exchange theory to distinguish procedural from interactional justice. Group and Organization Management, 27(3), 324-351.

33. Crow, M. S., Lee, C., \& Joo, J. (2012). Organizational justice and organizational commitment among South Korean police officers. Policing: An International Journal of Police Strategies and Management, 35(2), 402-423.

34. Dailey, R. C., \& Kirk, D. J. (1992). Distributive and procedural justice as antecedents of job dissatisfaction and intent to turnover. Human Relations, 45(3), 305-317.

35. Elamin, A. M., \& Alomaim, N. (2011). Does organizational justice influence job satisfaction and selfperceived performance in Saudi Arabia work environment? International Management Review, 7(1), 38-49.

36. Elovainio, M., van den Bos, K., Linna, A., Kivimaki, M., Ala-Mursula, L., Pentti, J., \& Vahtera. (2005). Combined effects of uncertainty and organizational justice on employee health: Testing the uncertainty management model of fairness judgments among Finnish public sector employees. Social Science and Medicine, 61(12), 2501-2512.

37. Erkutlu, H. (2011).The moderating role of organizational culture in the relationship between organizational justice and organizational citizenship behaviors. Leadership and Organization Development Journal, 32(6), 532-554.

38. Farahbod, F., Azadehdel, M., Rezaei-Dizgah, M., \& Nezhadi-Jirdehi, M. (2012). Organizational citizenship behaviors: the role of organizational justice and leader-member exchange. Interdisciplinary Journal of Contemporary Research in Business, 3(9), 893-903.

39. Fernandes, C., \& Awamleh, R. (2006). Impact of organizational justice in an expatriate work environment. Management Research News, 29(11), 70112.

40. Gilbert, S., Laschinger, H. K. S., \& Leiter, M. (2010). The mediating effect of burnout on the relationship between structural empowerment and organizational citizenship behaviors. Journal of Nursing

Management, 18, 339-348.

41. Greenberg, J. (1990). Employee theft as a reaction to underpayment inequity: the hidden cost of pay cuts. Journal of Applied Psychology, 75(5), 561-568.

42. Greenberg, J. (1993). Stealing in the name of justice: informational and interpersonal moderators of theft reactions to underpayment inequity. Organizational Behavior and Human Decision Processes, 54, 81-103.

43. Greenberg, J. (2006). Losing sleep over organizational injustice: Attenuating insomniac reactions to underpayment inequity with supervisory training in interactional justice. Journal of Applied Psychology, 91, 58-69. 
44. Halepota, J., \& Shah, M. (2011). An empirical investigation of organizational antecedents on employee job satisfaction in a developing country. Transforming Government: People, Process and Policy, 5(3) 280-294.

45. Haque, A., \& Aslam, M. S. (2011). The influence of distributive justice on organizational citizenship behaviors: Mediating role of emotional exhaustion and organizational attachment. International Journal of Business and Social Science, 2(15), 155-165.

46. Harlos, K. (2010). Anger-provoking events and intention to turnover in hospital administrators. Journal of Health Organization and Management, 24(1), 45-56.

47. Hassan, A., \& Hashim, J. (2011). Role of organizational justice in determining work outcomes of national and expatriate academic staff in Malaysia. International Journal of Commerce and Management, 21(1), 8293.

48. Hemdi, M. A., \& Nasurdin, A. M. (2008). Investigating the influence of organizational justice on hotel employees' OCB intentions and turnover intentions. Journal of Human Resources in Hospitality and Tourism, 7(1), 1-23.

49. Ince, M., \& Gül, H. (2011). The effect of employees' perceptions of organizational justice on organizational citizenship behaviors: An application in Turkish public institutions. International Journal of Business and Management, 6(6), 134-149.

50. Kamalian, A. R., Yaghoubi, N. M., \& Moloudi, J. (2010). Survey of relationship between organizational justice and empowerment (A case study). European Journal of Economics, Finance and Administrative Sciences, 24, 165-171.

51. Lambert, E., Hogan, N., Jiang, S., Elechi, O., Benjamin, B., Morris, A., \& Dupuy, P. (2010). The relationship among distributive and procedural justice and correctional life satisfaction, burnout, and turnover intent: An exploratory study. Journal of Criminal Justice, 8, 7-16.

52. Lee, C. Y., \& Liu, C. U. (2007). An examination of factors affecting repatriates turnover intentions. International Journal of Manpower, 28(2), 122-134.

53. Leng, K., Su, S., \& Morris, M. W. (2001). When criticism is not constructive: A cross-cultural investigation of responses to supervisory feedback as function of interactional justice. Human Relations, $54,1155-1187$.

54. Liu, S., \& Onwuegbuzie, A. (2012). Chinese teachers work stress and their turnover intention. International Journal of Educational Research, 53, 160-170.

55. Loi, R., Hang-Hue, N., \& Foley, S. (2006). Linking employees' justice perceptions to organizational commitment and intention to leave: The mediating role of perceived organizational support. Journal of Occupational and Organizational Psychology, 79, 101-120.

56. Lovel, S. E., Anton, J., Mason, C., \& Davidson, A. (1999). Does gender affect the link between organizational citizenship behaviors and performance evaluation, Sex Roles, 41, 469-479.

57. Macey, W. H., Schneider, B., Barbera, K., \& Young, S. A. (2009). Employee engagement: Tools for analysis, practice, and competitive advantage. London, England: Blackwell.

58. Mobley, W. H., Homer, S. O., \& Hollingsworth, A. T. (1978). An evaluation of the precursors of hospital employee turnover. Journal of Applied Psychology, 63, 408-414.

59. Moorman, C., Zaltman, G., \& Deshpande, R. (1993). Factors affecting trust in marketing relationships. Journal of Marketing, 57(1), 81-101.

60. Moorman, R. H. (1991). Relationship between organizational justice and organizational citizenship behaviors: does fairness perception influence employee citizenship? Journal of Applied Psychology, 76(6), 845-855.

61. Nadiri, H., \& Tanova C. (2010). An investigation of the role of justice in turnover intentions, job satisfaction, and organizational citizenship behaviors in hospitality industry. International Journal of Hospitality Management, 29, 33-41.

62. Niehoff, B. P., \& Moorman, R. H. (1993). Justice as mediator of the relationship between methods of monitoring and organizational citizenship behaviors. The Academy of Management Journal, 36(3), $527-$ 556.

63. Nowakowski, J. M., \& Conlon, D. E. (2005). Organizational justice: Looking back, looking forward. International Journal of Conflict Management, 16(1), 4-29.

64. Olkkonen, M. E., \& Lipponen, J. (2006). Relationships between organizational justice, identification with organization and work unit, and group-related outcomes. Organizational Behavior and Human Decision Processes, 100, 202-215. 
65. Organ, D. W. (1990). The motivational basis of organizational citizenship behaviors. Research in Organizational Behavior, 12(4), 30.

66. Organ, D. W., Podsakoff, P. M., \& MacKenzie, S. B. (2006). Organizational citizenship behaviors: Its nature, antecedents, and consequences. Thousand Oaks, CA: Sage.

67. Owolabi, A. (2012). Effect of organizational justice and organizational environment on turnover intention of health worker in Ekiti State, Nigeria. Research in World Economy, 3(1), 28-28.

68. Podsakoff, N. P., Whiting, S. W., Podsakoff, P. M., \& Blume, B. D. (2009). Individual-and organizationallevel consequences of organizational citizenship behaviors: A meta-analysis. Journal of Applied Psychology, 94,122-141.

69. Podsakoff, P. M., MacKenzie, S. B., Paine, J. B., \& Bachrach, D. G. (2000). Organisational citizenship behaviour: A critical review of the theoretical and empirical literature and suggestions for future research. Journal of Management, 26, 513-563.

70. Ponn, C. H., \& Chuan, C. C. (2010). Organizational commitment, organizational justice and employee turnover in Malaysia. African Journal of Business Management, 4(13), 2676-2692.

71. Rashid, W. E. W., \& Jusoff, H. K. (2009). Service quality in health care setting. International Journal of Health Care Quality Assurance, 22(5), 471-482.

72. Rezaiean, A., Givi, M. E., Givi, H. E., \& Nasrabadi, M. B, (2010). The relationship between organizational justice and organizational citizenship behaviors: The mediating role of organizational commitment, satisfaction and trust. Research Journal of Business Management, 4, 112-120.

73. Skarlicki, D. P., \& Folger, R. (1997). Retaliation in the workplace: the role of distributive, procedural, and interactional justice. Journal of Applied Psychology, 82, 434-443.

74. Suliman, A. M., \& Obaidli, H. A. (2011). Organizational climate and turnover in Islamic banking in the UAE. International Journal of Islamic and Middle Eastern Finance and Management, 4(4), 308-324.

75. Suliman, A., \& Al Kathairi, M. A. (2013). Organizational justice, commitment and performance in developing countries. Employee Relations, 35(1), 98-115.

76. Sweeney, P. D., \& McFarlin, D. B. (1993). Workers' evaluations of the 'ends' and the 'means': An examination of four models of distributive and procedural justice. Organizational Behavior and Human Decision Processes, 55, 23-40.

77. Tourangeau, A. E., \& Cranley, L. A. (2006).Nursing intention to remain employed: Understanding and strengthening determinants. Journal of Advanced Nursing, 55(4), 497-509.

78. Wang, X., Liao, J., Xia, D., \& Chang, T. (2010). The impact of organizational justice on work performance: Mediating effects of organizational commitment and leader-member exchange. International Journal of Manpower, 31(6), 660-677.

79. Whitman, D. S., Caleo, S., Carpenter, N. C., Horner, M. T., \& Bernerth, J. B. (2012). Fairness at the collective level: A meta-analytic examination of organizational justice climate. Journal of Applied Psychology, 97(4), 776-791.

80. Williams, S., Pitre, R., \& Zainuba, M. (2002). Justice and organizational citizenship behaviors intentions: Fair rewards versus fair treatment. Journal of Social Psychology, 142, 33-44.

81. Young, L. D. (2010). Is organizational justice enough to promote citizenship behavior at work? A retest in Korea. European Journal of Scientific Research, 45(4), 637-648.

82. Zhang, H., \& Naresh, C. A. (2009). The mediating roles of organizational justice on the relationships between HR practices and workplace outcomes: An investigation in China. The International Journal of Human Resource Management, 20(3), 676-693. 
NOTES 